\title{
Kari Sallamaa
}

\section{Anders Fjellner ja naisen väki}

Anders Fjellner (1795-1876) oli eteläsaamelaissyntyinen pappi ja runoilija, joka opiskeltuaan Uppsalassa 1800-luvun alkupuolella toimi ensin Jukkasjärvellä lähetyssaarnaajana ja Lars Levi Laestadiuksen apupappina Kaaresuvannossa saaden vuodesta 1843 kirkkoherran viran Lyckselen Lapin Sorselesta.

Fjellner on tunnettu ennen kaikkea runosta "Päivän pojan kosioretki jättiläisten maahan". Sitä on pidetty kansanrunona, muinaisjoikuna, jonka Fjellner olisi merkinnyt muistiin sekä kotiseudultaan, etelän Härjedalenista, että pohjoisesta, Tornion Lapista. Tosiasiassa ainuttakaan kansanomaista muistiinpanoa ei ole, joten runo lienee Fjellnerin oma kehitelmä. Hänen tavoitteenaan oli luoda saamelaisille kansalliseepos innoittajanaan Elias Lönnrotin Kalevala. Impulsseja hankkeeseensa täysin suomentaitoinen Fjellner sai myös opiskelutoveriltaan Uppsalassa, elinikäiseltä ystävältään C. A. Gottlundilta.

Fjellneriltä on tallessa kuusi runoa; loput ovat hävinneet tuhoutuneiden käsikirjoitusten mukana. 218-säkeinen "Päivän poika" on niistä tärkein. Siitä on useita toisintoja, niinpä saamenkielinen nimikin vaihtelee. Ensimmäinen on uumajalaisen papin ja kirjailijan J.A. Linderin vuonna 1849 ruotsin kielellä julkaisema proosaja runokooste "Sagoqvädet Solens söner", joka perustuu käsikirjoitukseen nimeltä "Peive-parnen Suongoh Jettanasi ilmin". Seuraavat täydelliset versiot sai kaksi Fjellnerin luona 1870-luvulla vieraillutta professoria, uppsalalainen anatomi Gustaf von Düben sekä Helsingin yliopiston sanskriitin ja vertailevan kielitieteen professori Otto Donner. Sokeutunut Fjellner saneli runon heille kuin Homeros ainakin.

Kun varsinkin saamelaiset kirjallisuudentutkijat Harald Gaski ja Vuokko Hirvonen haluavat nähdä runon folklorena, he eivät ole oivaltaneet sen ilmeisiä kiinnikkeitä epiikan kantavaariin, Homerokseen. Erityisesti nousee esiin Odysseian Nausikaa-efekti. Rantautuessaan Fjellnerin runossa Auringon maan miehet näkevät ensimmäiseksi kauniin pyykkärin: "Silmihin loistaa kuin aarre, / neito nuori Jättivallan, / sokean ukon ainut ompelija ./ Tulilla paitoja poukkaa: / vatvoo, vaivaa, vanuttaa, / huitoo, huuhtoo, valkaisee [--]" (Ks. Lundmark 1979, 126; suom. KS.) ${ }^{1}$

Vastaavalla tavalla Odysseian Nausikaa, faiaakkien saaren kuninkaan tytär, pesee orjattarineen jokisuussa isoa pyykkiä: "[M]ut vaunuist' itse jo vaatteet / nostivat pois sekä altaisiin vesiläikkyhyn veivät, / polkivat porskuttain niit' altaiss' ahkerin kilvoin" (Homeros 1962, 90.) On todennäköistä, että tämä Odysseian episodi on ollut Uppsalassa klassiseen kirjallisuuteen perehtyneen teologin mielessä. Prinsessoissa on samaa suoraa uljuutta, ihannenaisen ominaisuuksia. 
Kun Päivän poika voittaa prinsessan isän voimainkoetuksessa (tytön järjestämän hämäyksen avulla), isä suostuu antamaan tyttärensä aarremyötäjäisineen. Vuokko Hirvonen on viitannut runon seksuaalialluusioihin kohdassa, jossa tytär tiedustelee sulholtaan, kestääkö pursi kovempaa tuulta. Vastaus, jonka mukaan masto on vahva, on hänen mukaansa kuva joka ilmaisee "eufemistisesti fallista symbolismia". (Hirvonen 2000, 223-224.) Seksuaaliviitteet näkyvät myös neidon kätkiessä naisten varjelijan, Sarakka-jumalattaren kuukautissiteen. ${ }^{2}$

Kuten Satu Apo on osoittanut tutkimuskokoelmassaan Naisen väki, naisen sukuelimillä on suomalaisessa kansanomaisessa kulttuurissa mahtava voima, joka näyttäytyy monenlaisina tabusääntöinä, pelkoina ja magiana sekä vahingoittaa vastustajaa että suojata yhteisöä, perhettä ja sukua. Suomalais-karjalaisella alueella on loitsuja "vitun vihoja" vastaan, ja naisen elimen synty liittyy petojen kitaan. (Apo 1995, 14-, 27.) Jacob Fellmanin $(1906,331)$ - papin ja saamelaisen kansanperinteen kerääjän - kirjaamassa tarinassa taas naisnoita Piggan emättimestä lähtee yhdeksän sutta vastustajien kimppuun. Laura Stark-Arolan mukaan "vahingollinen voima karkoitettiin paljastamalla naisen sukupuolielimet tieten tahtoen sen läheisyydessä". Vagina oli väylä tämänja tuonpuoleisen välillä. (Stark-Arola 1998, 119.)

Fjellnerin mahtirunossa kyse on juuri tästä naisten sukuelinten voimasta: kun sisar haluaa karistaa takaa-ajavat veljensä kannoiltaan, kuukautisverinen liina on tähän tehokas väline. Sen väki vaikuttaa maagisesti pelastaen auringon pojan sekä laivan miehistöineen. Tytön kiihkeä toive päästä pois kotoaan motivoituu sukurutsan pelosta. ${ }^{3}$ Kesken ahdingon hänen mieleensä nousee kuitenkin halu: "Hääänkyyn juovattaa tahtoo. / Munaskuut mullii, lantio paisuu, / sukuveret virkoavat" (ks. Lundmark 1979, 128; suom. KS). ${ }^{4}$ Harvoin on runoepiikassa kuvattu naisen halua näin upeasti, avoimen konkreettisesti. Pappi Fjellner ei kaihtanut esittää tätä seksuaalista motiivia; hänelle se on tärkeä, oman kansan myyttisen synnyn edellytys.

Vaikka Fjellnerin runon nimihenkilö on patriarkaalisesti Päivän poika, runon tosiasiallinen päähenkilö on nimetön jättiläisten maan prinsessa. Nuorukainen on varsin passiivinen aktantti, joka voittaa vain tytön juonen avulla. Tytär taas on aktiivinen sekä isänsä lannistajana että veljiensä torjujana pakomatkalla. Hän pelastaa sulhasensa akkajumalattarien avulla - ja on sopiva saamelaisten alkuäidiksi, matriarkaatin perustajaksi.

\section{Viitteet}

1 "Tjalmai säjmahi allehahti / Neita nuora Jethanasen, / Tjäalmetes aijan aine kåårije,/ Svaiterin piktasit pessaa; / Tjålkotjättaa, tsapmattjättaa/ Njårothaa, kårkohtaa kårtjims/ Njabbodallaa, tabbodallaa/ Njammositis njalkotallaa,/ Wuoinomitis viilotallaa [- - ].” (Ks. Lundmark 1979, 126.)

${ }^{2}$ Von Dübenin $(1977,277)$ todistuksen mukaan kuukautisilla on saamelaisessa kansanuskossa suuri merkitys. Fjellnerin runossa neito tekee Sarakan liinaan kolmen akkajumalattaren 
solmut, joihin tuulet on sidottu. Tämä vastaa Odysseiassa Aioloksen tuulipussia. Solmumotiivin seksuaalista arkaluontoisuutta aikakauden häveliäässä kulttuurissa osoittaa se, että Gustaf von Düben kirjoittaa siitä latinaksi; suomeksi suunnilleen: ”Ensi yhdynnän veri pyyhittynä liinaan on tehokas taikaväline; liinan kolme solmua ovat 'neitsyyden solmuja', joista runossa puhutaan” (Düben 1977, 324; suom. KS.)

${ }^{3}$ Sigmund Freud pitää kulttuuriantropologisessa tutkielmassaan Totem und Tabu insestin pelkoa kaiken kulttuurin perustana. Hän näkee "luonnonkansojen” luomat klaanijärjestelmät, ryhmäavioliitot, toteemisidonnaisuudet ja tabukäsitykset eksogamian välineinä: ihanteena on naida oman heimon ulkopuolelta. Tabupeloista ja -kielloista tekijä viittaa mm. kuukautisiin ja lapsivuoteeseen kuitenkaan ilmoittamatta niiden syytä. (Freud 1989, 16-, 39-40.)

4 "Hääja juovagit haalidda / Njita njastaa, ruota påomaa / Puolva-värrah vajaltuoveh."

(Ks. Lundmark 1979, 128.)

\section{Lähteet}

Apo, Satu 1995. Naisen väki. Tutkimuksia suomalaisten kansanomaisesta kulttuurista ja ajattelusta. Helsinki: Hanki ja jää.

Düben, Gustaf von 1977 (1873). Om Lappland och lapparne, företrädevis de svenske. Jan Garnert (red.), Ethnografiska studier af Gustaf von Düben. 2. Utg. Stockholm: Gidlund.

Fellman, Jacob 1906 (1844). Anteckningar under min vistelse i Lappmarken. Andra delen. Helsingfors: Finska litteratursällskapets tryckeri.

Freud, Sigmund 1989. Toteemi ja tabu. Eräitä yhtäläisyyksiä villien ja neuroottisten sielunelämässä. (Totem und Tabu, 1913.) Suom. Mirja Rutanen. Helsinki: Love Kirjat.

Hirvonen, Vuokko 2000. How to Make the Daughter of a Giant a Sami - A Myth of the Sami People's Origin. Juha Pentikäinen in cooperation with Harald Gaski, Vuokko Hirvonen, Jelena Sergejeva \& Krister Stoor (eds), Sami Folkloristics. Turku: Nordic Network of Folklore, 215-231.

Homeros 1962 (750-650 eaa). Odysseia. Suom. Otto Manninen. 4. painos. Helsinki: WSOY.

Linder, J.A. 1849. Sagoqvädet Solens söner. Läsning för folket 15. Umeå.

Lundmark, Bo 1979. Anders Fjellner - samernas Homeros - och diktningen om solsönerna. Acta bothniensia occidentalis. Skrifter i västerbottnisk kulturhistoria 4. Umeå: Västerbottens läns hembygdsförening \& Västerbottens museum.

Stark-Arola, Laura 1998. Lempi, tuli ja naisten väki. Dynamistisista suhteista suomalais-karjalaisessa taikuudessa ja kansanuskossa. Jyrki Pöysä \& Anna-Leena Siikala (toim.), Amor, genus \& familia. Kirjoituksia kansanperinteestä. Tietolipas 158. Helsinki: SKS, 117-135. 